\title{
Allies among enemies: political authority and party (dis)loyalty in Bangladesh
}

David Jackman (University of Oxford) and Mathilde Maitrot (University of Bath)

Forthcoming, Modern Asian Studies

\begin{abstract}
The authority of political leaders in Bangladesh rests on diverse qualities, not least of which are the muscle and finance they can mobilize, and the relationships they can craft with senior party members. These are utilized to confront rivals both within and outside one's own party, competition which can be just as fiercely fought. In some instances, the intensity of intra-party competition can be so severe, that a further quality emerges: the capacity to find allies among enemies. Building local inter-party alliances can bolster the authority of politicians, yet severely detriment party coherence. This argument is developed through an analysis of mayoral and parliamentary elections over the past decade in a small Bangladeshi city, where a ruling party MP and opposition Mayor appear to have developed such a relationship. This has thwarted the electoral ambitions of their fellow party members, posing a serious challenge to party discipline. While political competition is often seen as being inter or intra party, here it is around inter-party alliances. This portrayal suggests we need to give greater emphasis to the decentralized and local character that political authority can take in Bangladesh.
\end{abstract}

Key words: Bangladesh, party politics, godfather, elections, alliances 


\section{Introduction}

In 2017 television channels and newspapers in Bangladesh broadcast images of a striking scene: a politician from the opposition Bangladesh Nationalist Party (BNP) bending down to touch the feet of the Prime Minister in a sign of respect. The scene was notable for a number of reasons. The BNP had for years been alleging widespread intimidation, election rigging, false police cases, and even the disappearance and extrajudicial killing of a number of their activists at the hands of the government. The figure was furthermore not a lowly leader but one of the senior most elected opposition politicians in the country, being inaugurated for a second term as Mayor of a city. From the perspective of the BNP then, here was one of their key leaders showing public deference to their rival, while their own party chief Khaleda Zia was facing court cases and likely conviction. Locally, in the politician's constituency, some members of the party later spoke of 'repercussions from top to bottom of the party' for the act, and were dismayed at what struck as disloyalty. What also makes the scene remarkable - as the Prime Minister patted the politician on the back smiling and read the inauguration oath - is that a major reason he had been elected was because one of the Awami League's own politicians had allegedly plotted behind the party's back to enable it.

This article tells the story behind this scene to examine a central theme within political analysis from South Asia and beyond: the character of political authority. Recent literature has illuminated the criminal and coercive character this often takes in the region (Piliavsky 2014; Vaishnav 2017; Jackman 2018a, 2018b; Michelutti et al 2018), where political 'bosses' resemble 'godfather', and rely on the skills of intimidation, violence and patronage for their career, built from a base of muscular cadre. At the same time, political leaders must also look up within the party hierarchy to build their 
career, crafting relationships with party seniors. When conceptualizing how these skills are deployed, it is common to identify two forms of political competition, that between rival parties (inter party) and that between party rivals (intra party, factionalism). The central argument developed in this article is that a further important skill of a local political leader, can also be at play: the capacity to find allies among enemies. Intra party rivalries can be so severe that they incentivize personal local alliances across parties, which can undermine a party's wider political ambitions, but bolster the authority of the politicians who builds them. This argument is developed through the case of a small Bangladeshi city, anonymised here as 'Dalipur', which has a sitting mayor from the opposition Bangladesh Nationalist Party (BNP), and a local MP from the ruling Awami League (AL). While nationally these parties are at loggerheads, locally these figures have developed an informal alliance, which functions to the personal benefit of both, enables them to dominate party rivals, and has hindered each party's wider local electoral ambitions.

The case also has significance for understanding Bangladesh's current political landscape, casting light on the character of political authority at a wider level. Nationally the ruling Awami League has steadily consolidated power over state and society during the past decade, increasingly deploying security agencies to scupper opposition, and taking a firm stance on the more flagrantly criminal elements within the party and associated bodies such as the youth (jubo) and student (chattra) wings. The BNP has been left with their party chief imprisoned from February 2018 (until recently), leaders facing a barrage of police cases, and the party's rank and file largely cowed and disillusioned. All of this indicates a highly centralized political machine. By

\footnotetext{
${ }^{1}$ Note that the names of politicians in 'Dalipur' have also been anonymised.
} 
contrast, the case here illuminates a more decentralized arrangement, where local authority can sit at a distance, but not detached, from the interests of Dhaka. Local politicians seek patronage and blessing from the higher echelons of their parties, yet equally, with a consolidated base, can find leverage close to the top of the party, and manipulate local events to thwart the interests of the party chief.

The primary fieldwork on which this article is based was conducted by the authors in Dalipur in June 2018. Research included twenty-five interviews with local politicians and activists from both parties, journalists, businessmen and members of the local police, that lasted between one and three hours. Alongside this we conducted a number of informal interviews with local residents (transport workers, labourers, small business owners) and participant observation of political events including iftar parties. Findings from this were then developed and verified iteratively through first, informal phone conversations with key informants; second, a series of further interviews with informants after the 2018 general election conducted by a research assistant; and third, a review of relevant media sources. The article proceeds as follows: the next section frames our analysis through literature on political authority in South Asia, before our case material examines political rivalries in Dalipur, elections in the city between 20082018, and cross-party alliances.

\section{Cultivating political authority in South Asia}

Much recent literature from South Asia has highlighted the profound disjuncture between normative visions of democratic politics and how it unfolds in practice, demonstrating that violence, criminality and patronage are integral to the functioning 
of democracy on the ground (Price and Ruud 2010; Piliavsky 2014; Gerharz and PfaffCzarnecka 2017; Vaishnav 2017; Jackman 2018a, 2018b; Klem and Suykens 2018; Michelutti et al 2018). With this has come a new academic vocabulary, with terms such as 'goonda', 'mafia', 'bosses' and 'godfather' increasingly used to denote the prevalence of muscular and criminal forms of politics in the region (Piliavsky 2014; Jackman 2018a; Michelutti et al 2018; Klem and Suykens 2018). This responds in part to the political vernacular on the sub-continent, where many such terms are commonly used, as well as to a perception that the region's politics is becoming increasingly criminalized. By one estimate for example, 34 per cent of elected parliamentarians in India's Lok Sabha faced criminal charges as of 2014, of which 21 per cent were 'serious' (relating to murder or kidnapping for example). This is a sizeable increase from 2004 when 24 per cent faced cases, of which 12 per cent were serious (Vaishnav $2017)^{2}$

A central concern of this literature is the character of political authority. This is portrayed as coercive, criminal and also heavily localized - with leaders 'sovereign' within their respective territories - relying on muscular cadre and the distribution of patronage, which they must carefully manage to sustain (Klem and Suykens 2018; Michelutti et al 2018; Ruud 2020). Hence, political leaders deploy thugs and gangsters, they 'create a crowd' (Ruud 2010) to show strength, and embody this in their own comportment. This is a skill honed in 'performances', through which people build reputations, and which is also sustained and embedded within wider practices of patronage and group mobilization (Klem and Suykens 2018; Michelutti 2018). On the

\footnotetext{
${ }^{2}$ While such a shift appears real, it has also been recognized that muscle is nothing new to the region's politics, with goonda (criminal, thug, gangster) for example long identified in both urban politics and crime (Jackman 2018a). Although the popularity of particular vocabulary may be new, the style of politics may be less so.
} 
ground leaders engage in widespread criminal practices such as extortion and racketeering as a routine part of political life (Martin and Michelutti 2017), understood within a moral framework where corruption is less to do with legality, and more with the failure to fulfill personalistic obligations (Piliavsky 2014: 169). Such dynamics also routinely intersect closely with labour politics (Jackman 2018b; Kuttig 2020). In Bangladesh this politics has been symbolized by, at the lower levels, a concern with gangsters and violent cadre in politics (Ruud 2014, 2018a; Jackman 2018a), and at a higher level, with the 'godfather' profiles of political bosses, typically MPs (Ruud 2018a, 2018b). While not all senior politicians warrant such a label, to write of 'godfather politics' alludes to the muscular character that politics in this context often takes.

The authority of such political godfather is not however constituted solely through their capacity to mobilize local muscle and finance, but also through their relationship to the political centre, with parties simultaneously appearing heavily centralized, and this connection having a significant bearing on the fortunes of political leaders (Ruud 2018a). Put simply, political ‘bosses’ (Michelutti et al 2018) look up to bigger bosses. The 'art of bossing' (Ibid) is thus one where political leaders navigate different fields, seeking to both solidify their base and cultivate relationships with senior party members, and ultimately the party chief. One means by which a politician's worth is measured is through their capacity not only to confront rivals in opposite parties, but also rivals within their own party (Ruud 2010; Suykens 2017; Jackman 2018b; Ruud 2018; Martin 2018; Kuttig 2019). Engaging in intra-party conflict (often termed factionalism, 'grouping' or daladali in a Bengali context) is a means of building authority within a party, essential to dominating rivals physically, and serving a 
'signaling function' to party seniors that you merit attention as an up and coming leader (Suykens 2018: 901). It is thus a crucial aspect to building political authority within one's locality, as well as with 'high command' (Ruud 2010: 95), enabling a leader to build connections with senior party officials who have power over political appointments.

A key space in which these skills are tested are elections to public office. Rather than primarily channeling the ideological preferences of voters, elections more fundamentally are institutions through which the strength of leaders, factions and coalitions is demonstrated (Khan 2010). In the run up to parliamentary elections contenders deploy the art of muscle politics, mobilizing their followers in shows of force, engaging in clashes with rivals, issuing electoral promises and distributing resources to influence voters. A crucial task for parties is to select the right local candidate. The precise qualities sought of course vary, in part according to the party's strategy, however factional conflict is useful to discern the leader with greatest base support and aptitude. The buildup to elections are hence often highly fractious, with political 'bosses' looking above and below hierarchically in their attempts to build and sustain their authority.

Elections are then windows into both the character of local politics, as well as an overarching politics where parties attempt to reconcile the interests between the political centre and periphery. As such, they can thereby reveal where power lies within broader party hierarchies. In the context of Bangladesh for example, there is a common perception that power resides firmly in the hands of party chiefs and those closely connected to them. Studies however reveal a more complex picture, where leaders close 
to the top are readily induced, pressure from below can significantly shape party decisions, and official party candidates are usurped by others. At the lower echelons of the party, such as aspiring student leaders in Rajshahi, the allocation of student posts appears to be administered in a more or less top-down manner, albeit shaped by the mediation of local political bosses (Kuttig 2019). Wider studies directly contest a vision of power as centralized within political parties, arguing this view needs to be moderated by an appreciation of the influence clientelist relations and local leaders have on party decisions (Khan 2020; Ruud 2020). One example of this is where intra-party factionalism has a highly detrimental impact on party resources and stability, even undermining official candidates, contrary to the expressed wishes of the party chief (Ruud 2018a). The case below develops this line of argument to highlight how local politicians can contradict and clandestinely undermine wider party interests, going so far as to build local cross-party alliances.

\section{Dynasties and rivalries in 'Dalipur' city}

Dalipur is a small Bangladeshi city close to the Indian border that was upgraded in status from 'municipality' to 'city corporation' in 2011, elevating its political representative from municipality chairman to city Mayor. In Parliament, it is a traditional stronghold of the opposition BNP, which the Awami League only won in 1973, and then not again until in 2008, after which it has remained in power. Despite the hold that the Awami League has had on the nation's politics throughout this period, Dalipur was one of seven city corporations that elected non-Awami League Mayors in $2012 / 2013^{3}$. The status of Mayor of a City Corporation is a much-coveted position,

\footnotetext{
${ }^{3}$ There are currently twelve city corporations in Bangladesh. Of the seven to elect a non-Awami League mayor in this period, most supported the BNP, one was from the Jatiya Party, and another a 'rebel' Awami League candidate.
} 
bringing significant authority, power over budgets and tenders, and in the case of the opposition, a lifeline to the party locally. ${ }^{4}$ It hence has national political significance. When won by the opposition, it can be a sign to the wider electorate that the incumbent has lost public support, and a source of momentum for the opposition in national politics. There is a long history of this. In early 1994 for example, during the final stages of the BNP's term in office, the Awami League won electoral victories in the Dhaka and Chittagong municipal elections, which it has been argued were an indictment of the BNP's public policies, and galvanized the opposition (Kochanek 1996: 707). In 2012/2013 the BNP found significant success in mayoral elections, enabled in part by a relatively 'free and fair' electoral environment, although this failed to then translate into electoral success at the 2014 general election, which the party boycotted. As of 2020, Dalipur is one of only two city corporations controlled by the BNP.

Across Dalipur, politicians, journalists and the police describe the city's political life in consistent and simple terms: political loyalties are divided into four primary groups (dal, group), with two in each party. Within the Awami League these groups are led by an aged political leader Shamsul Mollah, and by the current MP for the city's constituency (Dalipur-6) Abdul Haque. On the BNP's side groups are built around the current Mayor Majid Nasim, and the current secretary of the district BNP committee and MP candidate Nabil Uddin. Each of these leaders has extensive support in the city, commanding networks within their parties' respective affiliate organizations, and considerable vote banks. All also have had serious criminal charges and public allegations leveled against them, including murder, attempted murder, and corruption.

\footnotetext{
${ }^{4}$ Although city corporation status along with wider fiscal changes have brought increased budgets for public works, city corporations are still controlled heavily by central governments in much of their activities such as recruitment, taxation and planning (Panday 2017).
} 
The city's recent political history, our interlocutors described, could be understood through the competition and alliances between these four groups. This section therefore introduces these figures, sketching their political careers and local reputations.

Shamsul Mollah is an Awami League stalwart in the region, having been a Chhatra League leader pre-Liberation, Vice-President of a prestigious local college, a freedom fighter, and close with the Sheikh family ${ }^{5}$. He claims to have had a key role in establishing the Awami League in the region, that Bangabandhu requested his attendance when he travelled to the area, and described how Prime Minister Sheikh Hasina stayed in his home when touring the district. Although never an MP, he was two times general secretary of the party's Dalipur district committee, which was an elected position, as well as a Upazila Chairman, and at the time of research, the 14 party alliance $^{6}$ spokesperson in the District. Mollah portrays himself as a local philanthropist, having established and patronized a number of mosques and over 15 educational institutes in the area, many of which are named after the Sheikh family. The founding stone for one, named after Bangabandhu's wife, Sheikh Fazilatunnessa Mujib, was laid by the Prime Minister herself. Whilst being the figurehead of this group, he is also elderly, and more recently it has been his eldest child Nasreen Ayesha Ahmed and eldest son Mostafa Mollah who have contested the mayoral and parliamentary elections respectively from this dynasty, the latter of whom has also accompanied the Prime Minister on trade and diplomatic trips abroad. While then a distinguished leader, to his detractors he has a criminal image, is associated with land grabbing from Hindu

\footnotetext{
${ }^{5}$ The Sheikh family is a political dynasty at the helm of the Awami League. Sheikh Mujibur Rahman (known as 'Bangabandhu', friend of Bengal) is considered the 'father of the nation', the country's first leader post-independence. The current Prime Minister Sheikh Hasina is his daughter, and a number of wider family members are MPs.

${ }^{6}$ The fourteen party alliance is the political alliance led by the AL.
} 
families, corruption, oppression, violence and murders in factional party disputes. Some opposition activists described him as being tarnished by the fact one of his close relatives was killed in 'crossfire' with Rapid Action Batallion (RAB) (thereby associating him with criminality), and he himself being no better than infamous terrorists, the only difference being he is educated.

MP Haque meanwhile is a former municipality chairman, who stood unsuccessfully as a parliamentary candidate in the early 1990s and 2000s however is famed for bringing the city under Awami League control from 2008, and having broad appeal across the city. Shamsul Mollah described him as having been a lower ranking follower of his after independence, who joined him as he set up Chhatra League committees in the area, however broke away from his leadership and emerged as a rival, beating him in a municipal chairman election in the 1980s. To his supporters Haque is renowned as caring for his activists, providing them with whatever they need. His time in office over the past decade is however associated with a long list of criminal accusations informally made against him. Those heard include that he grabs land, has extorted businesses including a prominent local sweet brand, requires a cut of local land deals, informally receives 35 lakh taka a month from the local export processing zone (with prominent jute and garments residuals sectors), and perhaps most controversially that he shelters local drug traders. Many informants described the MP having formed a 'syndicate' with the police, sheltering drug smuggling from India, from which they all profit. Even prior to gaining power he was accused in a murder case by the caretaker government, and many wonder how he has accumulated the wealth he seems to have over recent years. His rivals allege also that he has donated money to schools aligned to BNP-Jamaat, has 
appointed a new public prosecutor with a Jamaat background, and is distant from the field, rarely visiting the houses of party workers.

On the BNP's side, current city Mayor Nasim's political lineage comes through his father (a prominent Muslim League leader), and also cousin, the decorated freedom fighter Lt Col (ret) Sayeed Hossain. Sayeed, as he was commonly referred to, was VicePresident of the United People's Party (UPP) early on in his career, a party founded in the early 1970s, and which formed part of Zia Rahman's (the founder of the opposition BNP) political alliance. He was then elected five times as an MP for the BNP and served as Minister for Energy and Mineral Resources, Environment and Forest, and Shipping. The BNP's popularity in Dalipur was put down largely to Sayeed and his dominance over local politics. One of Sayeed's strengths locally was his appeal across religious communities for not engaging in communal politics, being close with prominent Hindu leaders who had influence over the sizeable minority vote in the city. Nasim was a loyal follower of Sayeed, and involved with the Chhatra Dal from the late 1970s, later the Jubo Dal as district leader, and first elected municipality chairman in 2006.

During much of this period the BNP in Dalipur city were broadly united under the command of Sayeed. Two factors however changed this: Sayeed's death in 2006, and the emergence of the caretaker government in the same year. The caretaker government launched corruption charges against municipality mayor Nasim, forcing him to go into hiding ${ }^{7}$. One Awami League rival alleges that 'The last caretaker government made a list of 52 most corrupt people across the country, and Nasim was third'. With him gone,

\footnotetext{
${ }^{7}$ Nasim previously also had to go into hiding for part of the Ershad regime, after he was implicated in a murder case.
} 
and without Sayeed's authority to hold the party together, new leaders emerged, most notably Nabil Uddin who had previously run elsewhere as an MP candidate, however in the city previously only been the convenor of a thana committee. Nabil, the last of the protagonists introduced here, is a prominent local industrialist, with significant investment in the jute industry, and a central committee member. He is someone who 'doesn't do politics, politics is just his business. He is not a political figure', as a rival put it. For politicians on both sides of the party divide his primary quality is his financial clout. In the absence of Nasim (as the Mayor himself described it), Nabil became prominent, and now dominates local BNP committees.

These four groups then dominate local politics, making it difficult for political candidates to emerge outside of them. The character of competition between these groups is often violent. As one leader put it: 'I have everything to resist chaos. I have licensed arms as a freedom fighter, if anyone comes to do anything to us, I have an arrangement to deal with that. If you have this [pointing his finger as if a gun], no-one will dare to do anything'. Another leader described a readiness to fight if needed, that his rivals know he won't leave the ground if a clash breaks out. The violence varies in form and severity. During fieldwork alone (conducted primarily during Ramadan) iftar parties were being disturbed, the platforms and seating arrangements vandalised by rival groups as a show of force, a clash in the centre of the city broke out between the two BNP factions over the distribution of posts in the city Chhatra dal committee (where none of Nasim's men were given posts), and rival Chhatra league groups similarly clashed, leading to injuries and police arrests. More notably there had been a recent murder of a Chhatra league leader aligned to the MP, with those accused including sons of Shamsul Mollah, in a case they reject as conspiracy. Similarly, there 
was a long history of conflict between the BNP factions involving affiliate groups such as the Jubo Dal (the BNP's youth wing), in which pistols and rifles were a common sight. It is thus against a backdrop of political dynasties, rival groups and violence, that we can examine the politics of elections in the city.

\section{A brokered and broken agreement}

The degree of intra-party competition between these rival groups has shaped local politics in a way that threatens to undermine both parties' electoral ambitions, while arguably promoting the personal interests of leaders in office. To understand this we can trace how these rivalries have influenced recent mayoral and parliamentary elections. The rivalry between the Awami League's Mollah and Haque was so significant through the 1990s and early 2000s that the late BNP MP and former Minister Sayeed reportedly described in public as having two workers in Dalipur: Mollah and Haque. Their rivalry, in other words, did the BNP's job for them, enabling them to dominate local politics.

In the run up to the 2008 general election therefore this rivalry was mediated by a current senior Minister in the party chief's office, with the hope of bringing stability to the party locally. The agreement was that Haque would be made Awami League candidate for MP in the 2008 election, and that Mollah would be the AL's mayoral candidate. As Mollah described it: 'The party chief said to me, "BNP wins the election every time. This time help Haque become MP, and next time I shall provide for you"'. The objective sought was then a local balance between the contending groups. In agreement, Mollah followed the plan, supporting Haque, who beat BNP's candidate 
Nabil by a margin of over 20,000 votes. Quickly after winning the election however, it is claimed that Haque was aggressive towards his party rival, spoiling and disrupting the many education institutes their family owned. Despite the agreement, Shamsul Mollah and his family failed to win any locally elected position in either the parliamentary (2014 and 2018) or mayoral (2012 and 2017) elections.

Mayor Nasim was first elected as the Chairman of Dalipur Municipality in 2006 during the BNP last term in office ${ }^{8}$. The election was non-partisan, so rather than compete with the BNP's sheaf of paddy symbol, he competed with the electoral symbol of a duck, with his Awami League opponent competing with a pineapple. Although undeniably popular, even members of his group allege that the election was rigged, as one described: 'When Nasim was first elected mayor I personally sealed 186 votes. We were in power. This is the electoral system of our country. Before the election, we also gave voters TK1000 and made them swear upon the Quran holding it that they would vote for us.' When the caretaker government came into power he was suspended and went into hiding for 22 months, before returning and fighting his case in the Supreme Court. It was perhaps partly with such events in mind that the 2012 Dalipur election was the first in the country where all voters used Electronic Voting Machines (EVMs). This, along with significant presence of security agencies, enabled voting conditions widely viewed as comparably 'free and fair', despite a number of arrests on grounds of electoral bribery, and alleged intimidation in the run up to the day.

The use of EVMs followed their trial in a number of voting centres for the Narayanganj City Corporation in 2011 in which a 'rebel' Awami League candidate Selina Hayat Ivy

\footnotetext{
${ }^{8}$ This was before Dalipur received City Corporation status in 2011.
} 
beat the Awami League backed Shamim Osman. Dalipur saw an even worse loss for the Awami League, with Shamsul Mollah losing by a considerable margin to the BNP's Nasim. Why the Awami League decided to arrange the election this way is an open question, with some speculating locally that they wanted to demonstrate their popularity on the basis of development works they have achieved. Activists aligned to Shamsul Mollah described Haque as failing to campaign for him, sending a message to his followers that the candidate did not have his support. For rivals however, it was his own fault, and a reflection of his criminal image.

In response to this loss, Shamsul Mollah's family decided to compete in the 2014 parliamentary election, however failed to receive the party nomination, with it instead going to the incumbent MP Haque. In a pattern similarly seen across the country, the eldest son Mostafa stood as an independent candidate, becoming an Awami League 'renegade' or 'rebel' ${ }^{9}$. The family however again lost, with Mostafa officially registering over 38,000 votes to Haque's 59,000. It was widely alleged (by journalists, Awami League rivals and BNP politicians), that Haque had rigged the election. BNP leaders described Haque realizing he was losing to Mostafa, and directly going to the field himself and leading the rigging. In Mostafa's own words:

\begin{abstract}
'Basically the real result was different. The intelligence agencies congratulated me for the win, as I was ahead of the incumbent MP by 15 thousand votes, but the result was altered when it was declared. There was someone very powerful who did that. While the then DC [District Commissioner] for Dalipur was
\end{abstract}

\footnotetext{
${ }^{9}$ In 2014 'renegade' candidates were common, and many in fact beat the officially selected 14 party alliance candidate. In Dalipur-3 and Dalipur-4 for example, independent candidates beat the Jatiya Party candidates who had been allocated the seat as part of the alliance between the Awami League and Jatiya Party.
} 
transferred he disclosed to my father that actually I won the election and that it was because of an adviser to the Prime Minister that I lost. But we could not say much about it as our party is in government.'

Afterwards, Mostafa went to the Supreme Court with the intention of filing a case, however he described being convinced not to by the then Home Minister. Although a 'rebel', Mostafa claimed that this did not bring any negative consequences from the party after the loss.

\section{The 2017 mayoral race}

Following successive defeats for the Shamsul Mollah family, the daughter Ayesha was given the Awami League ticket for the 2017 mayoral election. The perception locally was that Sheikh Hasina had a soft corner for Ayesha, who had previously served as 'acting mayor' when the city was a municipality and was Vice-President of the Awami League Dalipur city unit. In giving her the ticket, the intention was to stop the rivalry, and provide a balance between competing groups within the party. Once again, however, the Shamsul Mollah dynasty failed, with the BNP's incumbent Mayor Nasim winning, even despite reports of ballot stuffing by Awami League cadre. It is widely claimed that their intra-party rival, MP Haque, was again behind this loss. In fact, his rivals argue, he has a long history for this. As Mostafa described it:

'Haque always go against Awami League candidates in every election in

Dalipur city. He is responsible for Awami League defeat of all the elections in 
Dalipur, he ran in the national election as independent candidate, and helped BNP to win. He doesn't actually belong to $\mathrm{AL}^{\prime}{ }^{10}$

While denied by Haque's followers, locally it is firmly felt that Haque had been actively maneuvering against Ayesha in the mayoral election. Prior to the election there were signs that senior party leadership were making significant effort to ensure an Awami League victory. Politically this was a crucial year prior to the general election, and a loss would signal weakness and give momentum to the BNP's attempts to destabilize the government and lead a mass movement to topple them. As has been common, for example, the police arrested a significant number of local BNP activists in the run up to the vote, which the opposition allege were often on trumped up charges of explosive cases. The allegation is that despite being directly instructed by the party chief to support her campaign, MP Haque was instead inactive. A close follower of Mayor Nasim described the consequences:

'In any election here, if the MP remains quiet, BNP wins. In the election, Haque didn't help Nasim directly, he just didn't act, he was indifferent. And that made the victory of Nasim possible. Awami League had deployed all its wings to ensure the victory in the election, but that failed. Now the party chief realized that there is no benefit being angry. Haque was totally inactive during the election, this is why Awami League candidate lost'.

\footnotetext{
${ }^{10}$ Previous electoral boundaries had meant that much of the southern part of the city was incorporated into a different constituency, Dalipur-8, and it was from here that Sayeed had been MP. In the 2001 general election Haque had ran as an independent against the official Awami League candidate, dividing the Awami League vote, and leading to victory with a very significant margin for Sayeed. As a result, he had reportedly been expelled from the Awami League for a number of years, even becoming an Awami League MP, without being a member of the Awami League.
} 
Others however claim that Haque went further, playing a game in the election, frustrated that a candidate he had supported was not given the party ticket, and careful not to see the power of his rival grow. With the intention of resolving the intra-party conflict, the party had used its extensive resources to bring about an Awami League victory. Haque was given responsibility to work in the south of the city, which is his electoral base. In practice however he failed to campaign, with some claiming his men even instructed locals to vote for the BNP. Mayor Nasim hence won more votes than expected in this side of the city. In the North meanwhile, a prominent Minister with close connections to the city had been given responsibility to manage the campaign. He assured Ayesha he would make sure she won, and Ayesha hence invested less time there. What MP Haque however arranged, it is alleged, is for the Border Guards to mobilize in that part of the city to ensure that the victory was 'free and fair' and that the Awami League could not manipulate the vote. One figure cited by journalists was that he paid them three crore taka, while also instructing the media to attend to that side of the city, ensuring that the fairness at the polling booths were maintained, thereby preventing the Awami League from manipulating the vote in this BNP-leaning constituency. As a previous mayoral candidate beyond these two described the 2017 election: 'The party asked Haque to work for the party nominee, but he secretly supported Nasim, now that is open. Everyone knows it. The party wanted to control him, but couldn't. He told the party that he was supporting the party candidate, but he did the exact opposite.'

A second facet to how the election unfolded as it did is the wider relationships with senior party figures that local politicians have to cultivate. These figures are important to the extent that the can influence key party decisions. Such relationships are often 
instrumental to receiving party nomination, but can also be used to sway the appointment of local party committees, and extend one's power base in other ways. Potential nominees and elected politicians build such channels throughout their careers, becoming aligned to particular figures. One source of weakness then for the Shamsul Mollah dynasty is their relative lack of success compared to MP Haque in maintaining such ties. The Shamsul Mollah family are now aligned closely to a then mid-ranking Minister, meanwhile MP Haque has managed to mediate a relationship with a more senior and current Minister.

Haque's rivals and journalists claim that although personal attachments behind such relationships are important, more fundamentally they are managed financially, with Haque relying on the black money that he has accumulated while in office. A common claim heard concerning this election, was that Haque had used his ties to pay off the senior party officials sent to help Ayesha (a party organizing secretary and joint general secretary). This, informants allege, also helps explain how the subsequent Awami League committee announced in the city have gone his way, with the figure of three crore taka again circulating as speculation on the sums involved. Mostafa describes this:

'It's wrong to say that the central committee people were sent here to help my sister win the city corporation election, because it was totally a game. They didn't even let me work for my sister's election... The MP [Haque] was supposed to be expelled from the party for his role during that election, but in fact he was given control to form the city committee just after. The people who were sent by the high command helped the committee to pass. But if they had 
conveyed the right report to the party chief, would she have made him president of the city committee knowing his role in the election?'

In the aftermath of the mayoral election, there is a sense that the central party's attitude towards MP Haque shifted. According to local journalists Haque was on the list of the 100 MPs whom the party was likely not to give the party nomination to again, however through managing these senior party connections now has absolute dominance in making committees in Dalipur and was re-elected again in the 2018 general election. The allocation of positions on committees can be a way for senior party officials to manage local factionalism, placating those who have lost out elsewhere. The suggestion here however is that through inducing senior party figures, the opposite has happened, with well-established leaders being neglected. A follower of Mayor Nasim described it like this:

'In the past, Sheikh Hasina didn't like Haque for the 'grouping'. Now he has proven that he has power. So she's left him to do everything. Sheikh Hasina tried to control the 'grouping' but it didn't work. Instead of demotion, now he is rewarded. He is everything in the city now'.

The perspective from the losing faction is that Shamsul Mollah has been involved in Awami League politics since the time of Bangabandhu, was committed even after his assassination in 1975, has made significant sacrifices for the party, been imprisoned and part of the Liberation struggle, and yet he is not being given 'the chair', is not receiving his fair recompense. It is furthermore claimed that when the question of who would be the next 'district administrator' was raised and Shamsul Mollah was 
forwarded because he was yet to receive any position, MP Haque was able to persuade senior Awami League leadership through his Minister contact to allocate the position elsewhere. Locals described the party high command thinking also that if Haque is not given the charge of forming committees there would be chaos, so better leave it to the side which has the strength.

\section{A not so secret alliance}

A highly controversial sub-plot to the factional rivalry within both the Awami League and BNP locally in Dalipur, and one that helps explain the strength of Haque and weakness of Shamsul Mollah, is the relationship that has formed between the BNP Mayor and local Awami League MP. It is an 'open secret', as it was often described, that there has been co-operation between the two. Despite the Mayor formally outranking the MP and local top police officials, the hierarchy in practice is reversed, with them having 'no obligation to obey me' as the Mayor put it. It was widely described that the MP and Mayor are so close that they call each other 'brother', with the MP seeing the Mayor as his younger brother, and the Mayor referring to the MP as the elder brother. Others referred to it as an 'apni' and 'tumi' relationship ${ }^{11}$. Images are spread locally through Facebook of the two together, with one photo circulating at the time of research in which they are hugging each other in public, both smiling. When they attend events together some people claim the onlookers are confused who belongs to which party ${ }^{12}$.

\footnotetext{
${ }^{11}$ The formal and informal Bangla pronouns for 'you', implying a hierarchical relationship.

${ }^{12}$ A similar relationship between local Awami League and BNP politicians been described in the city of Barisal (Ruud and Islam 2016; Ruud 2019). Here, the relationship functioned to the personal benefit of both, to the detriment of parties, and appeared largely driven by the need to maintain business interests. Ruud (2019: 284) describes this in terms of the Bengali notion of a 'balance' across
} 
The precise nature of this relationship is debated and disputed locally, and the subject of much discussion and conjecture. Some described it as an 'alliance', others a 'mutual understanding'. One BNP politician aligned to Nasim described it as 'a subtle understanding for personal benefits'. There are broadly speaking two narratives locally for this relationship, one positive, and the other negative. The first narrative is that the relationship is a pragmatic necessity to ensure that both figures can work for the public good. Loyalists to Nasim described BNP-AL conflict after the Mayor was first elected as city corporation Mayor in 2012, and that an understanding developed from this as a means for local peace. Mayor Nasim describes the relationship:

'If I quarrel with the MP and minister, I'll go to jail, and I won't be able to work for the people who elected me. This won't benefit people. So I won't tell a lie, I try to make an understanding with the MP and minister. I twice talked with the chairperson of my party, who told me to keep working, she said "I was prime minister three times, I know how to run office.” Because of this understanding with the MP, and the minister, I got works of tk400 crore. If my party was in power, I would have got more, but whatever I get now, I have to work with that for the people. As I made this understanding I get some cooperation from them, otherwise they won't give me works. I also do some works for the DC, SP, administrative officials, which is not my duty, still I do for the sake of the 'understanding',

powerholders, motivated also by intra-party competition, and the sense that 'your enemy's enemy is your friend and someone to be treated with care'. 
As a representative of the local government, he submits proposals to the Ministry for Local Government and Rural Development, who forward it to the ECNEC (Executive Committee of the National Economic Council), a body which recently allocated 84 crore taka to the city. The administrative process however requires political authorization, and without the support of the MP the claim is that their allocation would be blocked. For some of his supporters then, the relationship is portrayed less in terms of them as individuals, but more as a relationship between two positions of formal authority. It was an arrangement to 'keep his chair', a necessary step to avoid being put in jail, as has been the fate of other elected BNP mayors elsewhere in Bangladesh. It is also a political necessity for both men to ensure their popularity and to fulfill their political mandate to their constituents. Some supporters locally go so far as to portray it as a mature political compromise, an example of cooperation that is exemplary in Bangladesh, and if followed elsewhere, would bring a harmony to the nation's politics. Not only is this important for the Mayor, but the MP also needs this to deliver benefits locally. As it is local government that receives the funding, were they not to get the work, the lack of local visible development could dampen the MP's popularity.

Mayor Nasim however claims the relationship brings him little political benefit, narrating how $\mathrm{RAB}$ recently ransacked his entire house, and arrested his two brothers. Although they have an understanding, no Awami League leader comes to their aide. Others aligned to him similarly described the relationship as being of little benefit to the Mayor. For example, although there is cooperation, MP Haque leaves no space for the BNP to mobilise or develop their agenda locally. As one described it: 
'We can't hold rallies. We have asked permission to hold a rally in the town many times but were denied for everyone. The Mayor has a relation with the police, but the relationship has no worth because the police are ultimately controlled by the MP. Getting clearance from the MP is important for police permission. Police are the government's servant, the control of the administration is in hands of the government, and the MP is the government representative, so the administration can't do anything bypassing the MP in the system that we have. The system has become even worse in the last ten years.'

A second and contrasting local narrative to this relationship however portrays both in a rather more negative light. This raises allegations of widespread corruption, personal gain, and factional rifts in both parties, supporting the story told above around how Haque undermines his Awami League rivals. From this perspective, the relationship is central to the Haque - Shamsul Mollah rivalry, and part of how the MP has undermined rivals within his party. The most common refrain heard across the city from political insiders discussing this relationship is ' $60 / 40$ ', often said bluntly as if not needing to say any more. This refers to the division of resources the two allegedly appropriate through their elected positions, with 60 per cent going to the 'big brother' and 40 per cent to the 'little brother'. This relates primarily to the ability to distribute public works tenders, some of which are funded by international donors, but allegedly also involves extortion rackets and other forms of black money outlined earlier. A well-established BNP leader not aligned to Nasim nuanced the 60/40 arrangement:

'One hundred per cent of tenders are distributed illegally in Dalipur. Even the allotment of a shop is one hundred per cent illegal. It is distributed like this: the 
MP will take 35 per cent of the works, the 36 councilors of the city corporation take 35 percent, and the remaining 30 per cent goes to the Mayor. Then they sell these to $\mathrm{X}, \mathrm{Y}, \mathrm{Z}$, taking 12-15 per cent commission, no less than 10 per cent. Now if I get a work of TK1 crore, then first thing I have to do is give them TK12 lakh'

One alleged outcome of such practices are that poor quality inputs are used in the process, to maximize profit and enable the payments required to receive the contract. Local businesspeople interviewed were scornful of the development seen in Dalipur, which they perceived as minimal compared to that in comparable cities ${ }^{13}$. They described public works being done without a serious plan, and in some cases being done twice. For some the lack of development seen in Dalipur is an indication of the Mayor's corruption and inefficiency. For his supporters, any lack of development is due instead to the government neglecting the city because he is from the BNP and creating obstacles to their public works.

In line with this second narrative is the claim that the relationship enables Nasim to offer a degree of protection to his BNP followers, despite the condition of the party at a national level. At a time of widespread repression this is a rare commodity. In the run up to the 2017 mayoral election for example a number of Nasim's followers were arrested, however later released after he reportedly requested the MP to intervene with the police on his behalf. In such instances the MP is seen as obliging in order to keep

\footnotetext{
${ }^{13}$ A local businessman, and previous Awami League leader aligned to the Shamsul Mollah faction of the Awami League, described contracts for public works going to BNP contractors: 'Suppose, 100 tender are given, the MP will take 60 of those, the mayor rest 40 . Awami League workers are deprived. The MP sells these 60 works he gets to the BNP men. If you take me there, I can show you that BNP men are working every project. I was a class-1 contractor. But for the last ten years I have no work. For ten year! How can I afford to maintain my family?'
} 
the Mayor grateful to him. This cross-party arrangement has exacerbated the factional divides within the BNP locally, creating a resource stream for some and not others, and sprouting claims that the Mayor's faction is serving their own personal interests at the expense of the party's. A BNP city and district committee member not aligned to him describes it:

'We don't even get the smallest support from the mayor. BNP gets no privileges from him. He has been elected with the symbol of BNP, but actually he serves the interests of the MP. He's a coward. He doesn't have that mental strength to go against the government as a worker of BNP. That's why he's doing business, maintaining a liaison with the ruling party, and sharing works with them.'

Some even claim he purposefully downplays his BNP identity by underusing the party symbol in events. A local journalist described when Nasim was first elected as Mayor, the two groups from the BNP united for processions and events together in the city. When the MP saw that however, he made arrangements with Nasim. Now, when Nasim brings out procession, police simply follow them, but when the other faction bring out processions, then police baton-charge them. A district and city committee BNP member not aligned to Nasim describes this:

'The benefit of the negotiation for the MP is that he has been able to intimidate us considerably. Nasim's men are informing the MP what we are doing at the field level. They are also suggesting whose names should be to put on the list of the accused in the cases, and who should be harassed by the police' 
During the 2017 mayoral election BNP members aligned to Nabil, the BNP rival to Mayor Nasim, claim that they in fact worked constructively on the Mayor's side to help him win, partly to show that at a national level the BNP could effectively defeat the Awami League under free and fair conditions. After the election however the Mayor claimed they had actually mobilized for the Awami League. The intention behind this, they explained, was that were the Nabil group to be acknowledged as helping, the relationship would cost the Mayor a considerable share of the public works. This would thereby reduce his income and that of his group, and weaken him relative to his BNP rivals. The claim was then a strategy to create a distance. Similar to the allegations levelled against MP Haque, Mayor Nasim's detractors allege that it is only through amassing illicit money and paying party seniors that he has managed to win the nomination again. While being able to offer his followers some protection, this puts Mayor Nasim at odds with the wider party.

With the BNP failing in the elections in which they do compete, and boycotting many others, they are represented by very few elected politicians. Meanwhile leaders across with the party rank and file are allegedly being tortured, and falsely accused in criminal cases. To have a leader and his group enjoying relative safety while also seeming to compromise the party is a source of significant resentment. This has been exacerbated by Nasim's decision to bow down to the Prime Minister and touch her feet as a sign of respect (as is common with elders in a South Asian context) at his inauguration ceremony in 2017. Photos were widely shared showing the Prime Minister smiling and patting him on the shoulder. Even a close follower disagreed with this: 
'There will be repercussion from top to bottom in our party for this. He can exchange greeting at best, but he can't bow publicly, being the chief of a body. You know none of the other mayors from BNP have done this. They have many cases, they are away from office for a long time, but here he can sit in his chair'

Whether it is a direct result of this or not, the fact is that Nasim has managed to stay out of prison, whereas many of his fellow BNP mayors have spent years of their tenure jailed or too intimidated to attend their office.

\section{Conclusion}

The authority of political leaders in Bangladesh and wider South Asia is increasingly portrayed as coercive and criminal in character, with such dynamics understood as constitutive rather than contrary to democracy and wider political life (Vaishnav 2017; Michelutti et al 2018). Crucially, politicians are seen as existing and competing through patron-client networks, where they look vertically within parties; upwards to senior leaders and downwards to their base (Price and Ruud 2010; Piliavsky 2014). This article in part corroborates and builds on this work to explore where power is located in such hierarchies. The case study of Dalipur presented is complex. On the one hand our analysis highlights the importance of cultivating relationships with senior party level members for local politicians. There are allegations in Dalipur, which are widely believed locally, that it is only thanks to such ties that the ruling Awami League MP managed to cling to power in the 2014 election. Such relationships have to be carefully cultivated, are fragile, easily disrupted, and seemingly swayed by money. In the run up to the 2018 parliamentary elections Mostafa, the son of the Mollah dynasty, described 
looking for a senior party figure who could help him win the ticket, and how he was contemplating selling all his share of family land to be able to afford it. While ultimately unsuccessful in his ambition to receive the party ticket, his family did receive some reward when Ayesha, the eldest child, was allocated one of the fifty MP seats reserved for women, likely as an attempt to placate this losing faction of the Awami League in Dalipur.

More controversially however, the case of Dalipur contests a view of power as heavily centralized within such networks, tallying in this regard with other recent work from Bangladesh (Ruud 2020). The argument developed here is that a surprising source of authority for local politicians can lie in undermining their own party. Deeply pragmatic, local leaders can build informal arrangements with opposition in order to damage the authority and prospects of their party rivals, a dynamic we dub finding 'allies among enemies'. In our case, this alliance serves both the Mayor and the MP in different ways. By virtue of his status, the Mayor has greater access to resources for public development works than the MP, despite being a member of the opposition. It is an 'open secret' in Dalipur that the Mayor and MP share these resources, enabling a degree of personal enrichment and the ability to distribute resources to their followers. Were an Awami League Mayor elected, this stream of resources would likely dry up for the MP, and be directed towards a competing Awami League faction. With a BNP Mayor in power however, the MP has leverage, and can play the role of gatekeeper to the police and government, thereby maintaining the Mayor's dependency on him. For the BNP Mayor, the prospect of a local BNP MP would further diminish his strength locally within the party, where his supporters are already excluded from the city and other local party committees, despite him being in office. For both then, cross party alliances 
appear to represent a preferred outcome to supporting their fellow party members in other local elections.

Ultimately then, this argument also indicates that there are significant explanatory limits to understanding local political life through the prism of vertical party-based patron-client networks, offering an important contribution to wider literature from the region. In Dalipur it is partly by usurping the central wishes of the party that political authority manifests in its decentralized form. This suggests that the authority and careers of local politicians in Bangladesh - as likely also across wider South Asia - need to be read not only in terms of how they vertically within their own party network, but also the extent to which they look outside of their parties for sources of support and strength. The shape political competition takes here is not simply within or between parties, but crucially between inter-party alliances. On the other side of this divide from the Mayor and MP, Mostafa similarly spoke in positive terms of his relationship to the BNP Mayor's own party rival Nabil, and how this would be useful in his positioning for the then forthcoming election. Transcending party boundaries in this manner can thus enable complex games, in which politicians achieve leverage over both intra-party rivals, and the interests of senior party figures, enabling them to manoeuvre for status.

Contextually these dynamics must be read against the backdrop of the Awami League's attempts to dominate the country's politics and diminish the organizational strength of the BNP. Intra-party conflict can be a useful means by which party seniors judge the relative strength of contending groups within the party, enabling them to best judge who to allocate the party ticket to. When unable to discipline such competition however, it can foster party weakness. Our case suggests an inability of the party chief 
to discipline the MP given his control locally, whilst also highlighting the fickleness of senior party officials around the Prime Minister. ${ }^{14}$ Counter-intuitively, in Bangladesh these dynamics may in fact also be a means by which the ruling party can achieve hegemony, and opposition a slither of power. A prominent Awami League leader in the city reflected: 'can BNP come to power through their programs? No. So for them it's better to have a share than run political activities. And it's also good for the Awami League to control them by giving them a share of the money. If the Awami League don't give them this, BNP won't come under their control'. Nationally, it may well be through accepting and even cultivating such local compromises that the Awami League can contain opposition in the longer term, and also offer a route for the BNP to maintain a minimal party infrastructure. As a local BNP leader described Mayor Nasim through a Bengali proverb: 'something is better than nothing. It is better to have a blind uncle, than no uncle at all'.

\section{BIBLIOGRAPHY}

Faguet, J-P. 2017. 'Transformation from below in Bangladesh: decentralization, local governance, and systemic change'. Modern Asian Studies, 51(6): 1668-1694

Gerharz, E. Pfaff-Czarnecka. 2017. Spaces of violence in South Asian democracies: Citizenship, Nationalist Exclusion, and the (II)legitimate Use of Force. Asian Journal of Social Science, 45: 613-638

\footnotetext{
${ }^{14}$ In emphasizing the weight of local politicians in determining these elections, these argument mirror wider literature from Bangladesh concerned with decentralization, which has demonstrated how the character of governance, services and developmental outcomes differ dramatically across the country as a result of particular local social and political arrangements (Faguet 2017).
} 
Jackman, D. 2018a. 'The decline of gangsters and politicisation of violence in urban Bangladesh'. Development and Change, 50(5): 1214-1238.

Jackman, D. 2018b. 'Violent intermediaries and political order in Bangladesh'. European Journal of Development Research, 31(4): 705-723

Khan. A. A. (2020). 'Power, patronage and the candidate nomination process: Observations from Bangladesh'. Modern Asian Studies, 54(1): 314-336

Khan, M.H. 2010. Bangladesh: Partitions, Nationalisms, and Legacies for StateBuilding. SOAS Working Paper

Klem, B. Suykens, B. 2018. The Politics of Order and Disturbance: Public authority, sovereignty, and violent contestation in South Asia. Modern Asian Studies, 52(3): 753783

Kochanek, S.A. 1996. 'The rise of interest politics in Bangladesh', Asian Survey 36(7): $704-722$

Kuttig, J. 2019. 'Urban political machines and student politics in "middle” Bangladesh: violent party labor in Rajshahi city', Critical Asian Studies 51(3): 403-418

Kuttig, J. 2020. 'Labour power and bossing: local leadership formation and the partystate in 'middle' Bangladesh'. Contributions to Indian Sociology, 54(2): 193-214 
Martin, N. 2018. Corruption and Factionalism in Contemporary Punjab: An ethnographic account from rural Malwa. Modern Asian Studies, 52(3), 942-970

Martin, N. and L. Michelutti. 2017. 'Protection Rackets and Party Machines: Comparative Ethnographies of "Mafia Raj" in North India', Asian Journal of Social Science 45(6): 693-723.

Michelutti, L. 2018. 'Parivar Raj (Rule of Family): The Role of Money and Force in the Making of Dynastic Authority', Studies in Indian Politics, 6(2): 196-208

Michelutti, L. Hoque, A. Martin, N. Picherit, D. Rollier, P. Ruud, A.E. Still, C. 2018. Mafia Raj: The Rule of Bosses in South Asia. Stanford University Press

Panday, P.K. 2017. Reforming Urban Governance in Bangladesh: The City Corporation. Palgrave Macmillan

Piliavsky,A. (ed.) 2014. Patronage as Politics in South Asia. Cambridge: Cambridge University Press

Price, P. and Ruud, A.E. (Eds). 2010. Power and Influence in India: Bosses, Lords and Captains (Exploring the Political in South Asia). Routledge 
Ruud, A.E. 2010. 'To Create a Crowd: Students Leaders in Dhaka'. In: Price, P. and Ruud, A.E. (Eds). 2010. Power and Influence in India: Bosses, Lords and Captains (Exploring the Political in South Asia). Routledge

Ruud, A.E. (2014) 'The Political Bully in Bangladesh', in A. Piliavsky (ed.) Patronage as Politics in South Asia, pp. 303-25. Cambridge: Cambridge University Press.

Ruud, A.E. 2018a. 'The Osman Dynasty: The Making and Unmaking of a Political Family’. Studies in Indian Politics, 6(2): 209-224

Ruud, A.E. 2018b. The Godfather. In: Michelutti, L. Hoque, A. Martin, N. Picherit, D. Rollier, P. Ruud, A.E. Still, C. 2018. Mafia Raj: The Rule of Bosses in South Asia. Stanford University Press

Ruud, A. E. 2019. 'The politics of contracting in provincial Bangladesh'. In: HarrissWhite, B. and Michelutti, L. (Eds) The Wild East: Criminal Political Economies in South Asia.

Ruud, A.E. 2020. The mohol: The hidden power structure of Bangladesh local politics. Contributions to Indian Sociology, 54(2): 173-192

Ruud, A.E. Islam, M.M. 2016. 'Political Dynasty Formation in Bangladesh'. South Asia: Journal of South Asian Studies, 39(2): 401-414 
Suykens, B. 2018. 'A Hundred Per Cent Good Man Cannot do Politics': Violent selfsacrifice, student authority, and party-state integration in Bangladesh. Modern Asian Studies, 52(3): 883-916

Vaishnav, M. 2017. When Crime Pays: Money and Muscle in Indian Politics. Yale University Press 